\title{
Islam and Muslims in Early Nineteenth-Century British Poetry:
}

An Orientalist Perspective

Dr. Mohammad Ahmad Al-Leithy

Assistant Professor of English Literature

Department of English-Faculty of Arts -Arish University

\section{Abstract}

Early nineteenth-century British poetry (1801-1822) showed an unprecedented interest in Islam and Muslims. This paper investigates the most important Orientalist poems of the early nineteenth century. Most of the poems discussed in this paper are long ones, usually dubbed epics by their own authors. Such are poems like Southey's Thalaba the Destroyer and Roderick: The Last of the Goths, Scott's The Vision of Don Roderick, Byron's The Giaour,Childe Harold's Pilgrimage and The Corsair: A Tale, and T. Moore's LallaRookh. Two shorter poems are discussed. These are Coleridge's 'Mohammed: Mecca: Arabia', Shelley's Prologue to Hellas.

The paper shows that Islam was negatively presented by such poets. Almost all of the poems discussed show misinformation, accusations or prejudice against Islam and Muslims. Such inaccuracies and false claims about Islam and Muslims presented a distorted image of Islam and Muslims to European readers of the time.

Keywords: Islam, Muslims, Orientalism, Nineteenth Century, British, Poetry 
Islam and Muslims in Early Nineteenth-Century British Poetry: An Orientalist Perspective

\section{صورة الاسلام و المسلمين في الثعر البريطاني في مطلع القرن التاسع عشر: الثئر:}

\section{قراءة من منظور استثراقي}

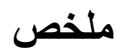

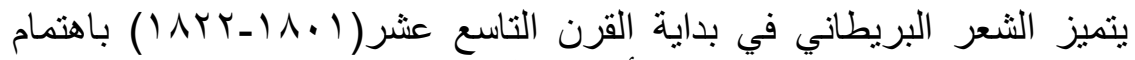

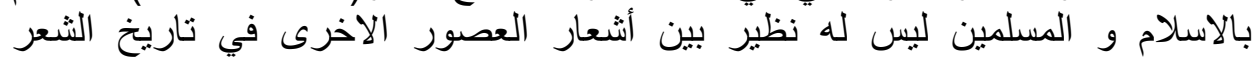

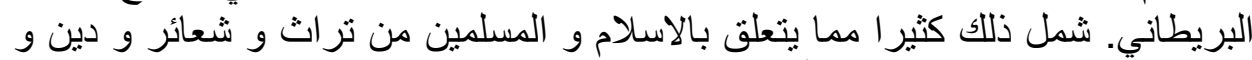

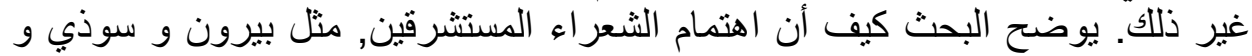

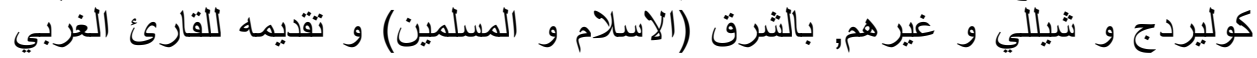
يفتقر الى الدقة و الصواب. نتج عن ذللك تشويه صورة الاسلام (شعائره و مقدساته) و و يبين البحث ما الت اليه صورة الاسلام و المسلمين في شعر تلك الفترة جراء التهاء

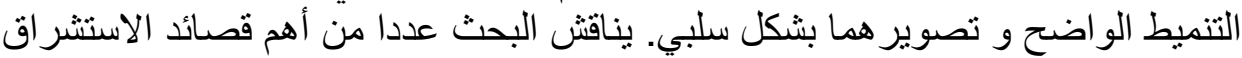

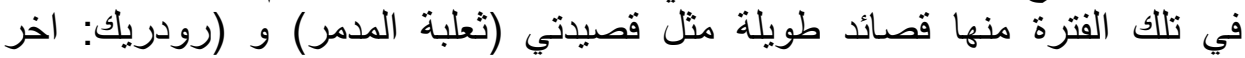

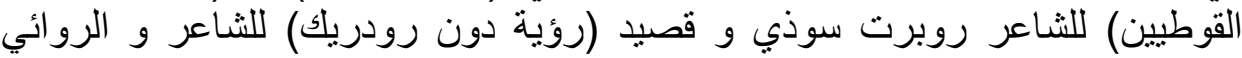

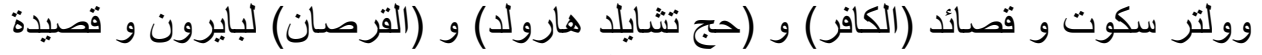

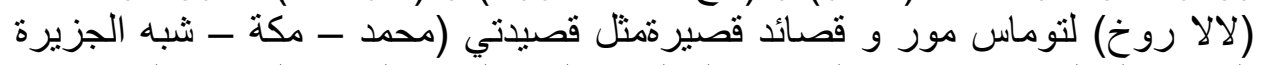

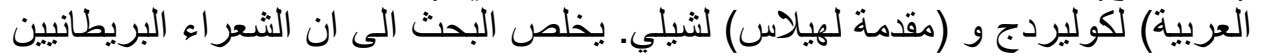

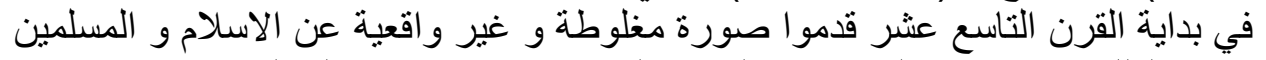
و كان لذلك سيئ الاثر على معرفة القارئ الغربي عن الأسلام و و المسلمين.

الكلمات المفتاحية: الإسلام ، المسلمون ، الاستشراق ، القرن التاسع عشر ، البريطاني ، الثعر 


\title{
Islam and Muslims in Early Nineteenth-Century British Poetry:
}

\author{
An Orientalist Perspective \\ Dr. Mohammad Ahmad Al-Leithy \\ Assistant Professor of English Literature \\ Department of English-Faculty of Arts -Arish University
}

Early nineteenth-century British poetry shows prejudice against Islam and Muslims. It can be said that English poetry of that period, approximately from 1801 to 1822, discloses an unprecedented interest in Islam and Muslims. Most English (used henceforth interchangeably with British) poets of the early nineteenth century, S. T. Coleridge, P. B. Shelley, Thomas Moore, Lord Byron and R. Southey among others, can be said to have mainly presented a distorted image of Islam and Muslims in their poetry. Such presentations resulted mostly in a negative image (remarkably exotic and sometimes erotic) not only of Islam as a religion, but of the Qur'an, Prophet Mohammad (peace be upon him) and Muslims as well. Nineteenth-century British poetry is, thus, accused of having played an important role in blemishing the images of Islam and Muslims.

Little attention has been paid to exploring Romantic poets' keen interest in the Orient as revealed in the poetic output of such poets. "Curiously, in an era in which conflicts worldwide between 'East' and 'West' dominate news headlines, ... literary and graphic responses to Islam have received scant attention from scholars" (Haggerty 27). It is the aim of this paper to show how most poets of the time represented Islam and Muslims negatively. In other words, the research aims at unveiling Orientalism in British poetry of the early nineteenth century.

Prior to discussing the poems, Orientalism will be introduced. The paper will come to grips with some of the most important poems of the time that featured Islam and Muslims. These include such long poems, usually dubbed epics, as Southey's

r.r.r. العدد السادس والعشرون (الجزء الاول)

مجلة كلية التربية- جامعة عين شمس 
Islam and Muslims in Early Nineteenth-Century British Poetry:

An Orientalist Perspective

Thalaba the Destroyer and Roderick: The Last of the Goths, Scott's The Vision of Don Roderick, Byron's Childe Harold's Pilgrimage, The Giaour and The Corsair: A Tale and T. Moore's Lalla Rookh and short poems such as Coleridge's 'Mohamed: Mecca: Arabia' and Shelley's Prologue to Hellas. The discussion mainly investigates the images these poems created of Islam and Muslims. The Conclusion states the findings of the research.

This research deals with one of the most crucial periods in British history, namely a time that witnessed the beginning of the building up and the expansion of the British Empire (1815-1914), the greatest empire of the time. In addition, at that time Greece was at war against Turkey, a war that came to stand in British Orientalist poetry for Christianity versus Islam as can be inferred from the works of such poets as Byron, Southey and Shelley. This research, thus, takes to its focal interest a critical periods in English literature, one during which Islam and Muslims were introduced to English and European readers.

The need for this research emanates from the belief that it is important to point out how early nineteenth-century poetry has importantly contributed to giving their readers false ideas about Islam and Muslims through misinformation, inaccuracies and prejudice. It further emanates from the fact that literary prejudice had a profound influence on distorting the image of Islam and Muslims by instilling and proliferating the idea that Muslims are such superstitious, lascivious and bloody people.

The paper will respond to some questions foremost among which are: in what way(s) did poets of that time represent Islam and Muslims? Why should such poets represent Islam and Muslims negatively as they did in many of their poems? To what extent can the Orient in Romantic poetry be associated and even identified, more than anything else, with Islam and Muslims?

Since this research is in line with Edward Said's assumptions, as revealed in Orientalism (1978), considered to be an

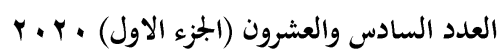

(78)

مجلة كلية التربية- جامعة عين شمس 
authority and a touchstone in Orientalist studies, it is appropriate at this point to shed some light on the assumptions of Orientalism as a school of literary criticism. Since its publication, Said's Orientalism has opened up many new, challenging vistas before readers and critics of English literature alike; it made rereading many of the works of English literature really demanding.

Said gives different definitions of Orientalism foremost among which is, probably, that of defining it as "that collection of dreams, images and vocabularies available to anyone who has tried to talk about what lies east of the dividing line" (73). Genuine to the book is the idea that the world has been divided into the East (Orient) and the West (Occident); the two are poles apart in the sense that each of the two stands for all that the other is not. According to Said, Orientalism "is fundamentally a political doctrine willed over the Orient because the Orient was weaker than the West, which elided the Orient's difference with its weakness" (204). Thus, the Orient versus the Occident distinction is not geographical inasmuch as it is cultural and, to a good extent, religious. Throughout the book, the Orient is often interchangeable with Islam and Muslims. Representing the relationship between the Arab/Muslim countries and Europe in English literature has often been expressed in terms of oppositions: East versus West, Orient versus Occident, Islam versus Europe, the One (West) versus the Other (East) and the superior (West) versus the inferior (East).

To begin with, Robert Southey was among the earliest poets of the century to write about the Orient. Southey, a British Poet Laureate for thirty one years, from 1813 to 1843, was keen on exploring Islam and presenting it to his readers; and this had a remarkable influence on his poetry. He is said to have read the Qur'an; George Sale's first volume of the translation of The Koran appeared in 1734, and the last in 1741. Southey's Thalaba the Destroyer and Roderick: The Last of the Goths are considered by many critics to be the poet's most notable poems about the Orient. In 1801, when he was twenty five years of age, Southey had his epic 
Islam and Muslims in Early Nineteenth-Century British Poetry:

An Orientalist Perspective

Thalaba the Destroyer, an unrhymed poem in twelve-books, published by Longman. The poem reveals the poet's deep interest in the East, the land of myths and dreams.

Thalaba the Destroyer does not, indeed, reveal a direct negative attitude towards Islam and/or Muslims as some other poems of the time do. Apparently, it reveals the poet's infatuation with the Orient. It can be said that one of the things taken against this poem is that it invests the stereotypical image of the Orient as it depicts a colourful world of magic, dancing women, sex slaves, superstitions, wine, "Myriads of Spirits", eroticism, murdering, vampires, beliefs, sorcery, charms, spells, mythical creatures, flying human beings, magicians, opening graves, wanderings through deserts and snow, sailing along rivers. This clearly contradicts with Nigel Leask's claim that "Southey presented Islam as a rational Unitarian religion" (Leask 26).

It is appropriate at this point to shed light on the double significance of the term Orientalism as explained by Shands since both meanings of the term, the old and the new ones, seem applicable to Thalaba the Destroyer. Shands comments on connotative changes of the terms 'Orientalist' and 'Orientalism' as follows:

In the pre-colonial days of Orientalist study, scholars were proud to call themselves Orientalists, and the very term - the Orient - was associated with magic... the Orient was revered as the cradle of civilization... to be an Orientalist meant nurturing a wish to transcend boundaries, to see Europe from a much larger perspective, not so much to search for differences between peoples as to see what we share as human beings. However ... today nobody dares define themselves as Orientalists since the word has acquired negative connotations (Shands 6). 
Overall, the reader gets the impression that the world represented in Thalaba is such a fanciful, superstitious one, which, in itself, is a distortion of the Orient. Significantly, this image and the like have largely stuck to the minds of many readers in the West.

Southey's use of proper nouns, especially names of people and places, reveal the poet's deep interest in the Orient and acquaintance with the Islamic culture and language. Some such names are Mohammad (pbuh), Harun al-Rashid, Lobaba, Okba, Laila, Moath, Zeinab, Khawla, Maimuna, Abdaldar, Oneiza, Baghdad, Babylon, simoom (strong, dry, dusty wind of the east).

Simply, the epic of Thalaba tells the story of a Muslim child named Thalaba. Prophecy has it that Thalaba will be chosen by God to conquer sorcerers, "Remember Destiny / Hath marked thee from mankind" (Warren 50). Sorcerers kill Thalaba's family but, together with his mother, Thalaba manages to escape. He finds a magic ring that a sorcerer has lost. The ring gives Thalaba superpower. A demon and a sorcerer try to steal the ring but in vain. Later in the narrative, Thalaba, in a fight with Muhareb, asks angels about how to defeat Muhareb, the angels tell him that it is through "faith".

While preparing to marry Oneiza, a woman that he enfranchised from Aloadin, Oneiza dies and Thalaba is struck by grief. Khawla and her sister Maimuna use magic to kill Thalaba, but the latter remains untouched by their evil plans. Laila, a sorcerer's daughter, falls in love with Thalaba. Laila's father tries to kill Thalaba, but Leila interferes and is killed by mistake. While sailing through a river, Thalaba throws his magic ring away. Fearlessly, he heads towards the cave where sorcerers meet. On the way, he faces challenges and dangers. He kills Efreet with an arrow in the eye. In the Domdaniel, the cave in the sea where sorcerers get together, Thalaba finds and takes his father's sword (of flames). The light of the flames intimidates the sorcerers who try to fight Thalaba; sorcerers are defeated. Finally, before Thalaba destroys the evil idol and the cave of the sorcerers, the voice of Prophet Mohammad (pbuh) is heard asking Thalaba what the latter wishes. Thalaba gives 
Islam and Muslims in Early Nineteenth-Century British Poetry:

An Orientalist Perspective

up his will to the prophet (pbuh). The poem comes to a close with this supposed dialogue between Thalaba and the Prophet (pbuh):

The all-beholding Prophet's aweful voice,

"Thou hast done well, my Servant!

Ask and receive thy reward!"

He answered to the Voice,

"Prophet of God,

Holy, and good, and bountiful!

One only earthly wish have I, to work

Thy will, and thy protection grants me that.

Look on this Sorcerer! Heavy are his crimes,

But infinite is mercy! If thy servant

Have now found favour in the sight of God,

Let him be touched with penitence, and save

His soul from utter death."

"The groans of penitence," replied the Voice

"Never arise unheard!

But for thyself prefer the prayer,

The Treasure-house of Heaven

Is open to thy will."

"Prophet of God!" then answered Thalaba,

"I am alone on earth.

Thou knowest the secret wishes of my heart!

Do with me as thou wilt! Thy will is best."

Thalaba knew that his death-hour was come, And on he leapt, and springing up,

Into the Idol's heart Hilt-deep he drove the Sword.

The Ocean-Vault fell in, and all were crushed.

In the same moment at the gate of Paradise,

Oneiza's Houri-form

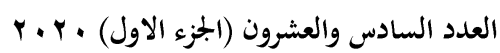

مجلة كلية التربية- جامعة عين شثمس 
Welcomed her Husband to eternal bliss (Einboden 137-8).

One of the things taken against the poem is that it represents the East as a world of magic and superstitions, a world that has nothing to do with real life. In so doing, the poem shows Muslims to be such a naïve people whose lives are largely overwhelmed by myths and superstitions. Thalaba was received with mixed reviews and responses. It is a tribute to the poem as some critics assert, that it was the first to introduce the vampire to readers of English literature. Furthermore, this poem can be said to have opened the eyes of a generation of poets to write about the Orient.

In his epic Roderick: The Last of the Goths (1814), Southey reveals a more negative attitude against Islam and Muslims. The poem is deemed to be Southey's greatest by many critics. It dwells mainly on the military encounters between the Spanish and the Moors, or, at a larger scale, between Islam and Christianity. Incidents in the poem start after the Moorish invasion of Spain, starting in 711, and Roderick's escape. Roderick has a recurrent dream of Christ bleeding which he interprets as Christ's call for him to restore Spain from the hands of Muslims. Often "would he see / The Cross whereon a bleeding Saviour hung" (Stevenson 37). Throughout the poem, Southey pinpoints the importance of religion and the Christians' need to unite against Muslims.

One of the important incidents in the poem is that of Adosinda whose children, as she says, were killed by the Muslim army. It should be pointed out that in Islam killing any non-warrior men, women or children is strictly forbidden. As told in the story, Muslims kept the woman to be a concubine. The woman manages to escape and she asks Roderick to avenge the murdering of her kids. She tells Roderick that the whole city has become a tomb for the inhabitants who have been mass slaughtered. The following lines from stanza twenty nine reveal the woman's misery and her asking for vengeance: 
Islam and Muslims in Early Nineteenth-Century British Poetry: An Orientalist Perspective

... she addrest him, ... there they lie,

Child, Husband, Parents, ... Adosinda's all!

I could not break the earth with these poor hands

Nor other tomb provide, . . but let that pass!

Auria itself is now but one wide tomb

For all its habitants :-

... ye, ye blessed Souls

Of Heroes and of murder'd Innocents,

Oh, never let your everlasting cries

Cease round the Eternal Throne, till the Most High

For all these unexampled wrongs hath given

Full, overflowing vengeance! (Stevenson 42).

The poem remarkably arouses Christians' feelings of anger and hatred against Muslims, and promises of vengeance. The poem can, thus, be said to provoke emotions of hostility against Islam and Muslims.

It is appropriate here to mention that Sir Walter Scott wrote a long poem on Roderick, but Scott's tells a different story. The Vision of Don Roderick, published in 1811, is Scott's most notable poem about the Orient. The poem has ninety five stanzas, each of which consists of nine lines. The following quotation reveals some of the concerns of the poem:

Don Roderick, the last Gothic King of Spain, is portrayed descending into an enchanted cave to learn the outcome of the Moorish invasion. Scott has two bronze giants reveal further visions of Spain's future: the Moorish dominion following Don Roderick's death, the restoration of Christian rule, the conquest of the New World, religious persecution, the slow decline of the increasingly corrupt Spanish court, 


\section{Dr. Mohammad Ahmad Al-Leithy}

down to the present day with Napoleon's invasion, the resistance of the Spanish patriots, and, finally, Wellington's brilliant victories (Barnaby).

Notable in the poem is Scott's depiction, in stanzas thirty two and thirty three, of Roderick's (who is supposed to represent the Spanish) panic over the news of the advent of the Muslim army:

They come! They come! I see the groaning lands, White with the turbans of each Arab horde, Swart Zaarah joins her misbelieving bands, Alla and Mahomet their battle-sword, The choice they yield, the Koran or the sword.

"By heaven, the Moors prevail! The Christians yield" (Books).

Like the previous poem, this one provokes European Christians to take action against Muslims whom the poet describes, in stanza eighty three, as "demons" and accuses them of being scornful of "God's great name".

In his turn, Lord Byron is, undoubtedly, one of the most important Orientalist poets of the century. Biographically, Byron visited Turkey, Albania and Greece in the years from 1809 to 1811, a journey which came to be known as Byron's Grand Tour. This is the journey during which he visited many mosques and historic places. Byron was impressed by the Turkish culture at the time. Greece and Albania represented European as well as Islamic cultures. Kada comments that Byron was generally impressed by the East at that time and that he admired the Ottoman governor Mohammed Ali Pasha greatly and spoke very highly of him (14). After returning to England, Byron wrote: 
Islam and Muslims in Early Nineteenth-Century British Poetry:

An Orientalist Perspective

The universe is a kind of book of which one has read only the first page when one has seen only one's own country. I have leafed through a large enough number, which I have found equally bad. This examination was not at all fruitless for me. I hated my country. All the impertinences of the different peoples among whom I have lived have reconciled me to her. If I had not drawn any other benefit from my travels than that, I would regret neither the expense nor the fatigue (Gross 85).

During his lifetime, Byron had a towering reputation not only in Britain but throughout Europe, chiefly due to his Orientalist poems. A large part of Byron's European reputation is undoubtedly due to his misrepresenting of the Orient in his poetry. Like the poetry of most Orientalists, Byron's was mainly satirical of the Orient. Furthermore, his Orientalist poetry focused on clash of cultures and religions rather than reconciliation and that makes religious tolerance inaccessible.

Byron is best remembered today as the poet of Turkish Tales. The Giaour, Childe Harolde's Pilgrimage and The Corsair are three of the best known poems of such tales. In the first of these, the poet gives his readers a clear picture of how he sees Islam and Muslims. The Giaour went through several editions in 1813, the year in which it was first published. In two years' time, the poem was published fourteen times, with some editing including additions of many lines; the first edition of the poem, in June 1813, had seven hundred lines while the last edition, in the same year, contained one thousand three hundred lines. Childe Harold's Pilgrimage is another notable poem of Byron's. It is worth mentioning that some critics assert that it was on publishing his Orientalist poem Childe Harold's Pilgrimage that Byron gained his unrivalled European reputation as a poet. "Childe", of the title, means son of a nobleman who has not yet attained knighthood. In its turn, Byron's The Corsair, sold ten

r.r. العدد السادس والعشرون (الجزء الاول)

مجلة كلية التربية- جامعة عين شمس 
thousand copies in its first day. Indeed, it can be said that Byron deliberately orientalised [italicising added] his poetry as all the above poems in addition to some others by the poet make clear. Even in his poetic masterpiece Don Juan (1819-24), a poem that is considered by many critics an autobiographical account of Byron the libertine in which Byron's private life is confessed under the guise of Don Juan, the poet does not miss the chance to season his poetry with an Oriental tale. This reveals not only the poet's own keen interest in the topic but European interest in and curiosity to read about that new world of the East.

Plots in Byron's Turkish Tales are dexterously interwoven. The narratives sequence the events in telling, memorable ways; they are further characterised by their simplicity. In addition, they adopt some important poetic devices and forms, such as refrains, heroic couplets, quatrains, personae, that make them memorable. The poet's invoking of the Muse in The Giaour and Don Juan is a convention traditionally adopted in epics. This shows how grand the poet believes his task to be. Invoking the Muse is a tradition adopted especially in epic poetry. It places the epic in line with such great epics as Homer's Odyssey $\left(8^{\text {th }} \mathrm{C}\right.$. BCE), J. Milton's Paradise Lost (1667) and E. Spenser's Faerie Queene (1590).

In 1812, Byron published the first two cantos of his poem Childe Harold's Pilgrimage. The third was published in 1816, and the fourth in 1818. The first two cantos gained the poet great European recognition at the time. They can be described as autobiographical, poetic accounts of the lands the poet had visited including Portugal, Albania, Spain and Ionia (in present-day Turkey). 'Canto the Second' opens with the poet's reflection on the great past of Greece, "Ancient of days! August Athena! Where, / Where are thy men of might, thy grand in soul?" (Knarf). Stanzas seventy nine to eighty three of Canto II focus on the occupation of Greece and its submission under the Turkish Empire. The poet expresses his sadness over the destruction the ancient Greek heritage at the hands of the Turks. The poet speaks of the Turks as 
Islam and Muslims in Early Nineteenth-Century British Poetry:

An Orientalist Perspective

profaning what is deemed sacred and holy by Christians. This simply means that Muslim Turks disrespectfully "pollute" Christian holy shrines and that this should be considered profaning to all Christians, rather than only to the Greeks. The stanza starts with the poet reflecting on the current miserable state of Greece under Turkish dominion. He uses the metonymy of "turbans" to refer to the Turkish soldiers, as Shakespeare did in Othello (Neill 396). The poet vilifies what he believes to be the oppressive nature of the Turks. He is angry the Turks "pollute" the sacred Greek shrines. What adds to the poet's deep sense of sorrow is that Greece stands helpless before the domineering and overpowering force of Turkey. The following is stanza seventy nine:

And who's more rife with merriment than thine,

O Stamboul! Once the empress of their reign?

Though turbans now pollute Sophia's shrine

And Greece her very altars eyes in vain:

(Alas! her woes will still pervade my strain!)

Gay were her minstrels once, for free her throng, All felt the common joy they now must feign;

Nor oft I've seen such sight, nor heard such song,

As wooed the eye, and thrilled the Bosphorus along (Galt 109).

In the second part of the stanza above, the poet reminds readers of what past Greece was like. The Greek then enjoyed happy times and never knew songs of lament. The poet's mentioning of "sight" and "hear[ing]"gives readers the impression that the poet is a trusted chronicler of what Greece was like. The present and the past sharply contradict in the stanza.

In stanza eighty three of the poem, the poet says that a trueborn son of Greece cannot but have the same feelings of love, loyalty and gratitude enough to enthuse him to defend this country

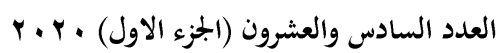

مجلة كلية التربية- جامعة عين شمس 
against the Turks. He urges the Greeks (and Europeans) to rise and take action against the Turks. He further laments that peace treaties between Turkey and Greece give the Greece only the "bondsman's peace" by keeping them under Turkish dominance. Thus, helplessly, the Greeks sigh for all they had lost. The poet is deeply sad the Greeks submissively yield to the Turks:

This must he feel, the true-born son of Greece,

If Greece one true-born patriot can boast:

Not such as prate of war but skulk in peace,

The bondsman's peace, who sighs for all he lost,

Yet with smooth smile his tyrant can accost,

And wield the slavish sickle, not the sword (Galt 109).

The canto ends with the poet's lamenting over the Turkish colonisation of Greece. The poet blames European countries outright for refraining from supporting Greece in its war against Turkey despite the fact that they owe a lot to Greece:

Ah, Greece! They love thee least who owe thee most-

Their birth, their blood, and that sublime record

Of hero sires, who shame thy now degenerate horde (Galt 109)!

1813 witnessed the publication of Byron's The Giaour, one of the most influential poems of the time. The Giaour /'dzavor/ is subtitled "A Fragment of a Turkish Tale". The word giaour, or Gavur in modern Turkish, means one outside the Islamic faith, an infidel. It is similar to the Arabic word "Kafir" which means blasphemer or non-believer ("Giaour"). The poem clearly exposes Byron's Orientalist attitude. The Giaour evokes a history of wars between the Ottoman Empire and some European countries, such as Greece and Cyprus. In 1362, the Ottoman Empire announced itself the Caliphate of the Muslim nation. The Orient was under Ottoman rule for nearly six centuries, from 1362 to 1924. The rapid and vast 
Islam and Muslims in Early Nineteenth-Century British Poetry:

An Orientalist Perspective

expansion of the Ottoman Empire alarmed the other European countries, of which some countries were actually under Turkish dominion. In addition to most Muslim countries, the empire included Greece, Albania, Bulgaria, Macedonia, Romania, Hungary and Israel. The Ottoman Empire, thus, became one of the largest empires in history. Here, as in some other poems, Byron "adopts an unfair attitude towards the Orient" (Khrisat 59). In Byron's Orientalist poems, the Muslim is the villain, the criminal and the transgressor. Like many other Orientalists, Byron combines the historical with the mythical.

The epic tells the narrative of Leila, one of Hassan Pasha's harem ('ha:ri:m), commonly defined as the wives or concubines of a polygamous man, who falls in love with the Giaour, who is a European non-Muslim. Leila elopes with the Giaour on one of the nights of Ramadan. She is punished by being drowned in the sea by Hassan. As explained by Byron, such is the punishment given to any Muslim woman who is found guilty of adultery in Turkey (the Muslim world). As the poem makes clear, more than anything else, Leila is drowned because of being unfaithful to Hassan with his enemy. One of the important messages of this poem is, of course, that women are such base, humiliated beings, mere slaves kept to satisfy men sexually. This is one of the ideas propagated in many poems of the time. Many such poems show that women live in submissive servitude and can simply be killed or drowned by men in case they make a mistake. These women, Leila for example, are looked at differently by the Giaour; they are greatly admired and respected:

She was a form of life and light

That seen, became a part of sight,

And rose, where'er I turn'd mine eye,

The morning-star of memory!

Yes, love indeed is light from heaven;

A spark of that immortal fire 
With angels shared, by Alla given,

To lift from earth our low desire (Galt 229).

Some Orientalist poets, it is to be noticed, harped greatly on the same string, i. e. of showing how Muslim men look disrespectfully and scornfully at women. Europeans, like the Giaour himself, are represented as greatly respectful of women, as will be pointed out. One more important idea is that such women slaves easily fall in love with Europeans as they admire European chivalry.

In revenge to Leila, the Giaour kills Hassan. Struck with a sense of guilt and remorse, however, the Giaour resorts to a monastery for redemption. Throughout reading The Giaour, readers discover the truth about each of the characters. Importantly, thus, by the time readers proceed through the poem, they are expected to ask some important questions foremost among which is, of course, who is really the giaour? Hassan, the lascivious, vengeful, bloodthirsty Muslim or the (noble, European) Giaour of the poem who acts nobly and loyally by avenging the unjust killing of his beloved Leila, and finally resorts to a monastery for redemption of his sins?

I loved her, Friar! Nay, adored --

But these are words that all can use --

I proved it more in deed than word;

There's blood upon that dinted sword,

A stain its steel can never lose:

'Twas shed for her, who died for me,

It warm'd the heart of one abhorr'd:

Nay, start not -- no -- nor bend thy knee,

Nor midst my sins such act record;

Thou wilt absolve me from the deed,

For he was hostile to thy creed:

The very name of Nazarene

Was wormwood to his Paynim spleen (Galt 226). 
Islam and Muslims in Early Nineteenth-Century British Poetry:

An Orientalist Perspective

The Giaour is sure he will be abandoned for killing Hassan Pasha as he acted out of nobility. Killing Leila is seen as a crime while killing Hassan is seen as a noble deed. One of the reasons Hassan deserved death, conformably with the Giaour's own words, is that he was "hostile to [the Friar's] creed". This can be, further, inferred from the following comment from The Norton Anthology of English Literature:

Pieced together, the fragments of Byron's "Turkish Tale" yield a story that combines doomed love with the clash of civilizations. A "Giaour" in the eyes of his antagonist ... the Christian hero of this poem goes to battle with the Muslim Hassan. His aim is to avenge the memory of Leila, the slave girl whom Hassan has had drowned after learning that she had been unfaithful to him with his enemy (Norton).

Describing the Giaour as a "Christian hero" in the quotation above is notable since this can be seen as the Christian hero fighting against the Muslim villain. The Giaour could have feared death and escaped, but heroically he returns and kills Hassan Pasha, who is represented as a mean criminal. Typical of the Byronic hero, the Giaour had better die than lose his chivalrous trait of nobility. To what extent, it should be asked, can the Giaour of the tale be identified with Byron himself who fought with the Greeks in their war of independence from the Ottoman Empire (1821-1831). It is worth remarking that Byron himself died while fighting with the Greeks in that war. Byron, "gave himself up to the cause of Greek independence which he upheld morally, financially and also in person, 1823; he died at Missolonghi (April 1824)" (Cazamian 1044-5).

This can, indeed, provide the poem with a further dimension, i. e. the symbolic one which can enrich the poem. Critics generally agree that, collectively, Byron's poems provide a clear mosaic of the poet's own personal life and thoughts. His poetry is an

العدد السادس والعشرون (الجزء الاول) .r.r.

مجلة كلية التربية- جامعة عين شثس 


\section{Dr. Mohammad Ahmad Al-Leithy}

amalgamation of the qualities that characterised Byron himself. Hassan can, thus, be accepted as representing traditional Islamic culture while the enslaved, helpless woman who is finally killed by Muslim Hassan can symbolise Greece itself and the Giaour can stand symbolically for Europe in its entirety.

The Turkey-Greece war was then an important issue. Most of the English poets of the time supported Greece. Byron was remarkably preoccupied with the idea of Greece being under the dominion of Turkey and this has turned out to be an important theme in a number of Byron's poems of which The Corsair: A Tale is one. Byron's The Corsair: A Tale (1814), written in heroic couplets, is another of Byron's Turkish tales. This is a long poem of nearly two thousand lines. Structurally, the poem is divided into three cantos, similar to Dante's Inferno, which the poet alludes to at the opening of each section. Conrad and Gulnare are two of the main personae in the poem. The former is the hero and the latter is a former sex slave. The poem tells the story of Conrad, a pirate, who plans to attack and rob Pasha Seyd's palace of its luxurious possessions. Conrad is adamant to pursue his plot despite his wife's pleas of refraining. The significance of the following lines should not escape the reader's attention:

Seyd is mine enemy: had swept my band

From earth with ruthless but with open hand,

And therefore came I, in my bark of war,

To smite the smiter with the scimitar (Galt 262).

He sets sails through the Aegean Sea. Disguised, Conrad, together with his banditti, attacks the Pasha's palace and plunders it. While escaping, however, Conrad hears the cries of the harem, i. e. the sex-slave women in the Pasha's palace. Out of nobility, he goes back to free them but is captured and imprisoned. Many of his comrades are killed but he had fearlessly killed a myriad of the Turks. Conrad is identifiable with the author, and, on a larger scale, with Europeans as will be pointed out. The speaker realises well that 
Islam and Muslims in Early Nineteenth-Century British Poetry:

An Orientalist Perspective

he is not infallible; he is erroneous, but he believes that he should be forgiven for whatever mistakes he has made for the one sole trait of nobility that he never gives up.

He knew himself a villain but he deem'd

The rest no better than the thing he seem'd;

And scorn'd the best as hypocrites who hid

Those deeds the bolder spirit plainly did.

He knew himself detested, but he knew

The hearts that loath'd him crouch'd and dreaded too (Galt 249).

One of the Pasha's harem named Gulnare decides to set Conrad free, out of her loyalty and gratitude to the bravery and nobility of the chivalrous man who tried to set such women slaves free. She tries to persuade the Pasha to set him free but the Pasha bursts angrily:

Release my foe! - At whose remonstrance? Thine!

Fair suitor! - To thy virtuous gratitude,

That thus repays this Giaour's relenting mood,

I have a counsel for thy gentler ear:

I do mistrust thee, woman! And each word

Of thine stamps truth on all Suspicion heard.

Borne in his arms through fire from yon Serai -

Say, wert thou lingering there with him to fly? (Galt 260).

The Pasha is so disrespectful of and suspicious about the woman. He threatens to kill Gulnare and Conrad. Gulnare goes stealthily to the cell where Conrad is imprisoned and tells him she intends to free

العدد السادس والعشرون (الجزء الاول) • r. r.

مجلة كلية التربية- جامعة عين شمس 
him. She concocts a plan of having Conrad killing Seyd Pasha so that Conrad will be freed. She takes a knife into Conrad's cell, but Conrad refuses as he is not ready to kill the Pasha treacherously in cold blood without a fair fight even though the Pasha was such a "hated tyrant" (Galt 261). Gulnare kills the Pasha herself. Conrad is freed and he takes Gulnare home with him. In this epic, as in the previous one, the symbolic significance of the characters, and of the events as well, should be considered. Enslaved Gulnare can, thus, symbolise Greece that should be freed from the Pasha's (Turkey's) grip by the European chivalrous Conrad. Only then can enslaved Gulnare be restored.

The tale is brought to a close with the notable lines, "He left a Corsair's name to other times, / Link'd with one virtue, and a thousand crimes" (Galt 265). Conrad (like Byron himself) believes that his sole trait of nobility should outweigh a thousand crimes and that he should be remembered as a noble hero. It should be asked if sabotaging, robbing and killing should really be justified by what is claimed to be noble intention. Byron's Corsair, it should be mentioned, was harshly criticised, by the Edinburgh Review, on the grounds that " $[\mathrm{t}]$ here is no intellectual dignity or accomplishment about any of his characters; and no very enlightened or equitable principles of morality" (Rutherford 62). Byron, however, defended his Conrad by comparing him to La Fitte, the New Orleans pirate, whose action of saving the lives of an officer and his men who were sent to kill him was accepted as chivalrous (Penelope).

Like Byron's, P. B. Shelley's main personae can be identified with the poet himself in the way they remarkably convey the poet's own ideological beliefs, particularly his political and religious ones, even though Shelley was a notorious atheist. Shelley's The Revolt of Islam (1818) is a clear example in this respect: 
Islam and Muslims in Early Nineteenth-Century British Poetry:

An Orientalist Perspective

The poem was produced by a series of thoughts which filled my mind with unbounded and sustained enthusiasm. I felt the precariousness of my life, and I engaged in this task, resolved to leave some record of myself. Much of what the volume contains was written with the same feeling, as real, though not so prophetic, as the communications of a dying man. I never presumed indeed to consider it anything approaching to faultless; but when I consider contemporary productions of the same apparent pretensions, I own I was filled with confidence. I felt that it was in many respects a genuine picture of my own mind. I felt that the sentiments were true, not assumed (Everest 11).

The Revolt of Islam was written under the title Laon and Cythna; or The Revolution of the Golden City and sent to the publisher in 1817 but Shelley withdrew it before publication and changed the title to The Revolt of Islam because of the poet's fear of prosecution. The glamour the word Islam added to the title must have been considered a privilege by both the author and the publisher, even though the title does not essentially reflect the content of the poem. This can support the claim that writing about Islam and Muslims was in vogue at the time. The poem only indirectly deals with the Turkey-Greece war of the time.

In 1817, the Irish poet Thomas Moore had his book-length epic Lalla Rookh published. Byron is said to have advised Moore to "stick to the East [as] the only poetical policy" (Bohls 155). He advised Moore to write a narrative poem with an Oriental setting some years earlier. The work is considered by many critics to be Moore's masterpiece; it was a bestseller at its time. On its publication, the epic attracted great attention of critics and readers

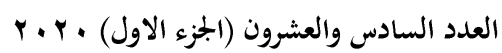

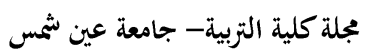


alike. "The most widely read Oriental poem in English was Thomas Moore's Lalla Rookh..., which presented Islam as a sensuous religion" (Varisco 15). The work was published twenty-one times during the author's life and Moore's reputation became second only to Byron's and Scott's. The poem was translated into many languages and it proved quite inspiring to painters, choreographers, composers and musicians who have for many decades dwelt on the work for various illustrations and adaptations.

Many critics read the epic allegorically as representing the relationship between England (the coloniser) and Northern Ireland (the colonised). Structurally, the outer frame of the epic is that of Princess Lalla Rookh's journey from her father's kingdom in Delhi to her betrothed Aliris's palace in Bucharia (Bukhara). Four embedded narratives are dealt with within this outer frame. Such are "The Veiled Prophet of Khorassan", "Paradise and the Peri", "The Fire-Worshipper", and "The Light of the Harem". The following quotation reveals the possibility of the double interpretation of the poem:

"The Fire Worshipper," a tragic romance given the perfunctory background of the war between Muslims and Zoroastrians, is actually about Ireland's struggle to be free and the hanging of Robert Emmet in 1802, whereas "The Veiled Prophet," another ill-fated love story this time against the Caliphate, is actually a meditation of the French Rvolution. But the veiled Prophet, who stands in for Napoleon, perhaps also has something of Daniel O'Connell about him. The stories are overwritten lush with excessive beauty, glittering jewels, sumptuous palaces, as well as being coy and tearfully sentimental (MacLean 135). 
Islam and Muslims in Early Nineteenth-Century British Poetry:

An Orientalist Perspective

This reading of Moore's Lalla Rookh enriches the meaning of the poem. This is supported by the poet's own note in the introduction to the work that, "The spirit that had spoken in the melodies of Ireland soon found itself at home in the East" (Gwyn 81). This is remarkably true with Hashem al-Muqanna'a's (meaning the veiled) rebellion against Muslims' dominion over Persia, as told in the first of the epic's four narratives.

The eponymous princess is the daughter of Aurungzeb, Muhi-ud-Din Muhammad (1618-1707), the $17^{\text {th }}$-centuey Mughal emperor (1658-1707). In Persian, Lalla Rookh literally means the "tulip cheeked". Princess Lalla Rookh is sent to King Aliris's palace to be married. Aliris's father, King Abdalla, is the ex-king of Bucharia but he abdicated his throne to his son Aliris, a smart and wise young man. Readers are told that Abdalla has, "set out on a pilgrimage to the Shrine / of the Prophet". This is incorrect as Pilgrimage is performed in Mecca, not in the Prophet's shrine, which is in Medina. King Aliris sends his own cavalcade to meet and conduct the Princess's one.

The narratives of the epic abound with false ideas about Islam and Muslims. To give examples from the first narrative, Azim, the hero of the first story, is sent by al-Muqanna'a to fight against the Caliph. Azim's beautiful beloved Zelica is told that her lover Azim was killed in war. She joins the harem of al-Muqanna'a believing that in so doing, she will reunite with Azim in Paradise. This is not true from an Islamic point of view. Later in this part of the poem, Azim discovers the truth about deceitful al-Muqanna'a and joins the Caliph's army against al-Muqanna'a's one. When about to be captured, al-Muqanna'a commits suicide. Zelica, who does not know the truth about the evil al-Muqanna'a feels desperate as she becomes unsure about joining her lover in Paradise after the suicide of al-Muqanna'a. This is another fallacy as this way of 
thinking is by no means Islamic. Veiled as al-Muqanna'a, Zelika decides to fight against the Caliph's men. In the battle, she is mistakenly attacked and fatally wounded by Azim. The two lovers reconcile only when Zelica was breathing her last. Stricken with grief, Azim remains to the side of his beloved's grave the rest of his life. Just before Azim's death, Zelika's spirit appears to Azim in a vision and the two souls are united in death. This idea of lovers being united in death does not exist in Islam. Stanza ninety six of the poem reads:

She, for whose spirit he had pray'd and wept

So many years, had come to him, all drest

In angel smiles, and told him she was blest!

For this the old man breath'd his thanks, and died.

And there, upon the banks of that lov'd tide,

He and his Zelica sleep side by side (Fleischer 40).

It should be admitted that poetry is not supposed to be telling the truth. It should, however, be acknowledged that in that era, probably more than any other, it was mainly through poetry that the Europeans came to know about the Orient. Proliferating false ideas about the Muslim nation and religion in such an excessive way resulted in a distorted image of Islam and Muslims.

The poems discussed above are long ones. Almost all of them are called epics by their authors. The poems that follow are shorter and terser ones. Coleridge's 'Arabia: Mecca: Mohammed' and Shelley's Prologue to Hellas are two important poems in this respect. The poems are more succinct and sharper in their attacks. Coleridge's is a Petrarchan sonnet, one of the most popular and most concise forms of the poem in English, in which the speaker, remarkably Coleridge himself, launches several attacks on Prophet Mohammad (in the octave) and on Islam and Muslims (in the sestet), even though the poet, ironically, calls the poem a song. 
Islam and Muslims in Early Nineteenth-Century British Poetry: An Orientalist Perspective

Coleridge's poem, thus, reveals an antagonistic attitude toward Islam and Muslims. Coleridge encompasses his attacks on Islam and Muslims. According to the poem, Islam is God's punishment for Christians for not spreading their religion. The poem, thus, encourages Christians to take serious steps to spread their religion. In a mocking tone, the poet will sing of "the flight and return of Mohammad" which refers to the prophet's Night Journey and Ascension into Heaven and his coming back during the same night. He describes the Prophet as the founder of a "huge wasteful empire" characterised by "slow persecution". The poem opens with the poet encouraging his soul to utter the song:

Utter the song, $\mathrm{O}$ my soul! The flight and return of Mohammed,

Prophet and priest, who scattered abroad both evil and blessing,

Huge wasteful empires founded and hallowed slow persecution,

Soul-withering, but crushed the blasphemous rites of the Pagan

And idolatrous Christians. For veiling the gospel of Jesus,

They, the best corrupting, had made it worse than the vilest.

Wherefore Heaven decreed the enthusiast warrior of Mecca,

Choosing good from iniquity rather than evil from goodness (Beer 27).

The poem essentially reveals Coleridge's views on Islam and Muslims. The poet is wondering why God chose "Mohammed", "the warrior of Mecca", to be his prophet. The Prophet's Night Journey and Ascension into Heaven are referred to in the first line.

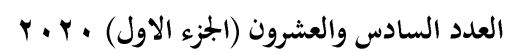

مجلة كلية التربية- جامعة عين شمس 
According to the poem, it is the Prophet of Islam who crushed the rites of Christians who he considers Pagans. Furthermore, as the poem makes clear, he considers Christians to be the vilest as they hid the Gospel of Jesus. This is not true as the Qur'an teaches Muslims everyone has the freedom of belief (Ghali 297 ) and that that "[ $t]$ here is no compulsion in religion" (Ghali 42). In addition, the Qur'an tells Muslims that the nearest of mankind to Muslims in affection are those who say "We are Nasara" (Ghali 121).

In the sestet, the poet launches several attacks on Muslims and mocks their religious rituals of Hajj (Pilgrimage). The poem presents Muslims as idolatrous idiots:

Loud the tumult in Mecca surrounding the fane of the idol;

Naked and prostrate the priesthood were laid, - the people with mad shouts

Thundering now, and now with saddest ululation

Flew, as over the channel of rock-stone the ruinous river

Shatters its waters abreast, and in mazy uproar bewildered,

Rushes dividuous all, - all rushing impetuous onward (Beer 27).

Islam is presented as disparagingly demolishing other beliefs even though its followers are idiot savages who practice idolatrous rituals as the poem makes clear. Islam is represented as an enemy of mankind, its prophet as an imposter and a ruinous despot and Muslims as mindless followers. In their turn, rituals of Islam are mocked in the poem: Muslims' prayers, recitation of the Qur'an and supplications in Mecca are described derogatorily as "mad shouts". 
Islam and Muslims in Early Nineteenth-Century British Poetry: An Orientalist Perspective

More serious is the false claim that Muslims circumambulate naked around the Ka'ba.

The claim that Islam has priests is also groundless. Coleridge, like many of the century's poets, insisted on showing Muslims as followers of a deviant man who has created his own religion or, at best, that Prophet Mohammad (pbuh) is a deviant Christian. This explains why some Orientalist poets insisted on seeing Islam as Mohammadanism and Muslims as Mohammadans. Coleridge probably saw Islam to be a distorted version of Christianity devised by Prophet Mohammad (pbuh), and this explains why he used such words as "priest" and "priesthood", in the second and tenth lines of the poem above. It is worth noting that, more than two centuries before, Christopher Marlowe made the same mistake in Tambourlaine the Great in which eponymous Tamburlaine expresses some of the vilest and most hostile notions about Islam, Muslims and the Qur'an:

In vain, I see, men worship Mahomet:

My sword hath sent millions of Turks to hell,

Slew all his priests, his kinsmen and his friends,

And yet I live untouched by Mahomet.

There is a God, full of revenging wrath,

From whom the thunder and the lightning breaks,

Whose scourge I am, and him will I obey.

So, Casane; fling them in the fire.

[They burn the books.

Now, Mahomet, if thou have any power,

Come down thyself and work a miracle.

Thou art not worthy to be worshipped

That suffers flames of fire to burn the writ

Wherein the sum of thy religion rests.

العدد السادس والعشرون (الجزء الاول) •. r.

مجلة كلية التربية- جامعة عين شمس 
Why send'st thou not a furious whirlwind down.

To blow thy Alcaron up to thy throne.

Where men report thou sitt'st by God himself.

Or vengeance on the head of Tamburlaine

That shakes his sword against thy majesty.

(Elizabethandrama II: Act V, Sc. i, )

The lines express the idea that Muslims worship Prophet Mohammad (pbuh) which is utterly incorrect and groundless. The Prophet is also depicted as divinely sitting next to God. Such is misleading information. Rejection of Islam and the burning of the Qur'an are considered heroic deeds in Marlowe's Tamburlaine the Great.

Shelley's Prologue to Hellas is another poem (a short verse drama) of the time that mocks Islam and Muslims. Shelley was recommended by fellow poets and some publishers of the time to write a poem on the ongoing war between Turkey and Greece. Prologue to Hellas was the result. Shelley wrote the poem in Pisa, Italy, in 1821 and sent it to be published in England in 1822. To the poet's own surprise, the poem received great critical acclaim on its publication, "[ $\mathrm{t}]$ he only "goat-song" which I have yet attempted has, I confess, in spite of the unfavourable nature of the subject, received a greater and more valuable portion of applause than I expected or than it deserved" (Delphi 38). In the preface to the poem, the poet comments on the valour and fearlessness the Greeks have shown in their war against the "the Turkish tyrant" and declares that it is the duty of whole Europe to rise and support Greece in this war; he calls for a "holy alliance" similar to that claimed during the Crusades. He even goes on to assert enthusiastically that, "we are all Greeks. Our laws, our literature, our religion, our arts have their root in Greece" (Thomas 1). Sympathising with the Turks in one way or another, the poet asserts, is treason and a crime, "an indelible blot that a country may brand upon its name" since the Turks, which he calls "the 
Islam and Muslims in Early Nineteenth-Century British Poetry:

An Orientalist Perspective

common enemy" are the "enemies of domestic happiness, of Christianity and civilisation" (Stock 124).

Mohammad and Jesus (peace be upon them) are among the dramatis personae in the Prologue. The poem ends with the assumed words of Prophet Mohammad (pbuh) who enthuses Muslim warriors to pursue their advance in the lands of Europe and orders them to be a "curse" on Christians who are polytheists:

Haste thou and fill the waning crescent

With beams as keen as those which pierced the shadow

Of Christian night rolled back upon the West, When the orient moon of Islam rode in triumph

From Tmolus to the Acroceraunian snow (Frowde 550-1).

The crescent symbolises Islam; Muslims follow the lunar calendar. Filling the crescent means conquering the world and spreading Islam in all parts of the globe so that the crescent will become a full moon. This, according to the poet, represents Islam's overall dominance of the world. As expressed by the poet, Muslims are urged to defeat and crush the Christians for being polytheists:

Wake, thou Word

Of God, and from the throne of Destiny

Even to the utmost limit of thy way

May Triumph

Be thou a curse on them whose creed

Divides and multiplies the most high God (Frowde 550-1).

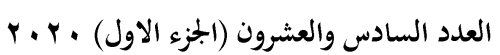

مجلة كلية التربية- جامعة عين شمس 
In this last speech of the poem, Shelley gives a supposed voice to Prophet Mohammad (pbuh). In so doing, Shelley tries to reveal Islam and Muslims' notions about Christianity and Christians as aggressively hostile. According to this speech, the crescent of Islam should reach all the countries of Europe to illuminate their darkness of creed. The crescent starts its endeavour throughout Europe from Mount Tmolus (in Turkey) and Acroceraunian Mountains (in Albania). That Islam is God's punishment to Christians who balk at spreading Christianity can be inferred. The lines, further, imply the idea that it is Christians' inaction that encouraged Muslims to reach European lands and threaten their creed which Muslims see as corrupt as the poem states. The idea finds its counterpart in Coleridge's 'Mohammed' discussed above. This contradicts with religious tolerance that Islam orders its followers to maintain. To give one example, Prophet Mohammad (pbuh) recommended Muslims to treat the Copts of Egypt kindly as they "have a right of kinship on you" (Islamweb). It is notable that propagating false notions about the Orient in such a persistent way has resulted in creating a stereotyped image of the East (Islam and Muslims) as enemies of the West.

Most of the poems discussed in this paper were published between 1801 and 1822. This research is conducted within the framework of tracing and uncovering the veins of Orientalism that remarkably extend throughout the British poetic oeuvre of the early nineteenth century. Its objective has been to show that there was some tendency among British poets of the time to represent Islam and Muslims. Poets of such an era presented Islam and Muslims negatively to their readers. It is not difficult to figure out certain aspects are in common among many British poets of that time. Indeed, it is true that poets of the time encouraged one another to write poems about the Orient. The result was a largely disfigured imaging of Islam and Muslims.

This British Orientalist poetic discourse has largely contributed, through a tradition of misinformation and groundless 
Islam and Muslims in Early Nineteenth-Century British Poetry:

An Orientalist Perspective

accusations about Islam and Muslims, to creating an unbridgeable gap between the East and the West. Many nineteenth-century English readers saw Islam and Muslims through the eyes of such poets most of whom wrote about Islam out of their imagination or depending on other works of literature, such as Marlowe's Tamburlaine the Great, rather than out of real experience, by reading authentically about Islam and Muslims or by travelling to countries of the East. As a result of such poetic production, the East was mainly misrepresented as exotic and erotic.

Common features can be figured out in most Orientalist poems of such poets as Southey, Byron, Shelley, Coleridge and others of the period. These include Muslim men being deeply involved in sex, Muslim women being looked at humiliatingly by Muslim men as harem, concubines and sex slaves. On the other extreme, Christian Europeans are such chivalrous, noble men who are ready to fight to free such oppressed women and defeat the mean, villain Muslims. In addition, Islam is depicted as a religion built on superstitions and Muslims as being mindless people, followers of an imposter. Muslims, thus, need to be guided and civilised. More serious is the idea that Islam is represented as God's punishment for Christians for refraining from spreading His Word. Orientalist poets presented Muslims as backward people following false beliefs and practicing idolatrous rituals. In its turn, Islam itself is nothing but a false and superstitious creed. 
Dr. Mohammad Ahmad Al-Leithy

\section{Works Cited}

Archive.org/stream/rodericklastofg00soutuoft/rodericklastofg00soutuoft djvu.txt

Barnaby, Paul. Edinburgh University Library. walterscott.lib.ed.ac.uk/home.html

Beer, John. Coleridge's Play of Mind. New York: Oxford University Press, 2010.

Bohls, Elizabeth A. Romantic Literature and Postcolonial Studies. Edinburgh: Edinburgh University Press, 2013.

Books.google.com.sa/books?id=yRMeAAAAMAAJ\&printsec=titlepage

\&redir_esc $=\mathrm{y} \# \mathrm{v}=$ onepage $\& \mathrm{q} \& \mathrm{f}=$ false

Cazamian, Louis and Raymond Las Vergnas. A History of English

Literature. Great Britain: J. M. Dent \& Sons, 1967.

Delphi Classics. Percy Bysshe Shelley: Complete Works. Sussex, 2013.

Einboden, Geffrey. Islam and Romanticism: Muslim Currents from Goethe to Emerson. London: Bloomsbury, 2014.

Elizabethandrama.org/wp-content/uploads/2017/09/Tamburlaine-Part-

Two Annotated.pdf

Everest, Kelvin and Geoffrey Matthews (ed.). The Poems of Shelley: 1817-1819. London: Routledge, 2014.

Fleischer, Ernest (ed.). The Works of Thomas Moore. Ohio: Leipsic, 1926.

Frowde, Henry. The Poetical Works of Percy Bysshe Shelley. London: Oxford University Press, n. d.

Galt, John. The Complete Works of Lord Byron. Paris: Baudry's European Library, 1973.

Ghali, Muhammad Mahmud. TowardsUnderstanding the Ever-Glorious Qur'an. Egypt: Publishing House for Universities, 1997.

"Giaour." The American Heritage College Dictionary. Third Edition.

New York: Houghton Mifflin Company, 1993.

Gross, Gonathan David, Byron: The Erotic Liberal. Oxford: Rowman and Littlefield, 2001.

Gwyn, Stephen. Thomas Moore. New Zealand: The Floating Press, 2013.

Haggerty, Sarah and Jon Mee (ed.). Blake and Conflict. New York: Palgrave, 2009.

Islamweb.net/en/fatwa/83732/hadith-regarding-egypt

العدد السادس والعشرون (الجزء الاول) •. r.

(107)

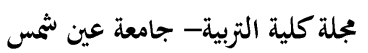


Islam and Muslims in Early Nineteenth-Century British Poetry:

An Orientalist Perspective

Kada, Wafa. Orientalism in Lord Byron's Turkish Tale The Giaour.

University of Tlemsan, Faculty of Letters and Languages, Master's Degree Dissertation, 2017.

Khrisat, Abdulhafeth Ali. "The Image of the Oriental Muslim in Lord Byron's The Giaour (1813)". English Language and Literature Studies; Vol. 8, 2018, 17-12-2019, p. 59-70.

Knarf.english.upenn.edu/Byron/charold2.html, 3 Aug. 2019.

Leask, Nigel. British Romantic Writers and the East: Anxieties of Empire. Cambridge: Cambridge University Press, 2004.

MacLean, Gerald (ed.). Britain and the Muslim World: Historical Perspectives. New Castle: Cambridge Scholars Publishing, 2011.

Neill, Michael. Othello, the Moor of Venice. Oxford: Oxford University Press, 2008.

Norton.com/college/english/nael/romantic/topic 5/byrongiaour.htm

Penelope.uchicago.edu/Thayer/E/Gazetteer/Places/America/United_State

s/Louisiana/_Texts/LHQ/2/4/Lafitte*.html

Rutherford, Andrew. Lord Byron: The Critical Heritage. London:

Cornwall, 2013.

Stevenson, Allan H. A Study of the Roderick Legend in English Poetry by

Scott, Landor and Southey. 1926. Texas: Houston. M. A.

Dissertation.

Said, Edward. Orientalism. New York: Vintage Books, 1994.

Shands, Kerstin W. (ed.). Neither East nor West: Postcolonial Essays on Literature, Culture and Religion. Sweden: Sodertorns hogskola, 2008.

Stock, Paul. The Shelley-Byron Circle and the Idea of Europe. New York:

Palgrave Macmillan, 2010.

Thomas, Carol G. (ed.). Paths from Ancient Greece. New York: E. J. Brill, 1988.

Varisco, Daniel Martin. Orientalism and Islam: Bibliographies Online Research Guide. Oxford University Press, 2010.

Warren, Andrew. The Orient and the Young Romantic. Cambridge: Cambridge University Press, 2014.

r.r. العدد السادس والعشرون (الجزء الاول)

(108)

مجلة كلية التربية- جامعة عين شمس 